\title{
QUALITY OF WORK LIFE, ORGANIZATIONAL COMMITMENT AND TURNOVER INTENTION IN ACCOUNT OFFICER OF MICRO FINANCE COMPANY
}

\author{
Adinna Astrianti ${ }^{1}$, Mukhamad Najib ${ }^{2}$, dan Bagus Sartono ${ }^{3}$ \\ ${ }^{1}$ Sekolah Bisnis, Institut Pertanian Bogor, Jl. Raya Pajajaran, Babakan, Kecamatan Bogor Tengah, Kota Bogor \\ ${ }^{2}$ Departemen Manajemen, Institut Pertanian Bogor, Jl. Agatis Kampus IPB Dramaga, Bogor, Jawa Barat 16680 \\ ${ }^{3}$ Departemen Statistika, Institut Pertanian Bogor, JL. Meranti Wing 22 Level 4, Bogor, Jawa Barat 16680 \\ E-mail: adinnastrianti@gmail.com
}

\begin{abstract}
The purpose of this study is to analyze the effect of quality of work life ( $Q W L)$ on turnover intention through organizational commitment of account officers in micro-finance company. This research was conducted using the survey method. Data were collected using questionnaires from 115 account officers at a micro-finance company in West Java. Data were analyzed using descriptive statistics and SEM-PLS. The results of this study indicate that QWL has a significant and positive effect on organizational commitment and organizational commitment has a significant and negative effect on turnover intention. It can be concluded that by increasing the implementation of QWL will increase the organizational commitment of employees to remain in the company so that it decreases the intention of employees to move or leave the company.
\end{abstract}

Key words: account officer; organizational commitment; QWL; turnover intention

\section{KUALITAS KEHIDUPAN KERJA, KOMITMEN ORGANISASI DAN TURNOVER INTENTION PADA ACCOUNT OFFICER PERUSAHAAN PEMBIAYAAN MIKRO}

\begin{abstract}
ABSTRAK. Tujuan penelitian ini untuk melihat pengaruh quality of work life (QWL) terhadap intensi turnover melalui komitmen organisasi pada account officer pada perusahaan pembiayaan mikro. Penelitian ini dilakukan dengan menggunakan metode survey. Data dikumpulkan menggunakan kuisioner dari 115 account officer pada salah satu perusahaan pembiayaan mikro di Jawa Barat. Data dianalisis menggunakan statistik deskriptif dan SEM-PLS. Hasil penelitian ini menunjukkan bahwa QWL memiliki pengaruh yang signifikan dan positif terhadap komitmen organisasi dan komitmen organisasi memiliki pengaruh yang signifikan dan negatif terhadap niat turnover. Hal ini dapat disimpulkan bahwa dengan meningkatkan penerapan QWL akan meningkatkan komitmen organisasi untuk tetap berada di perusahaan sehingga menurunkan niat karyawan untuk berpindah atau keluar dari perusahaan.
\end{abstract}

Kata kunci: Account Officer, Intensi Turnover; komitmen; QWL

\section{INTRODUCTION}

Human Resource is an important asset in an organization or company. Each company has different vision and mission, that one of which must be supported by Human Resource (SDM). The success of vision and misson achievement of a company needs support from quality and competent Human Resource.

Turnover is one of the serious problems that must be faced by company. Turnover intention is a behavior attitude of someone to pull themselves from organization, meanwhile turnover illustrates an actual action in releasing self from an organization (Aydogdu and Asikgil 2011). Zhang et al. (2015) said that company cannot be operated welliftheiremployees whoare competenthaveintelligence, skill, or higher motivation, resigned voluntarily. The lost of employees that happen in a company can affect the running business. Turnover can cause negative effect to company, where company lost experienced employees and company must recruit new employees and need to train those new employees which makes company spend more fund and time. Company must conduct evaluation to why employees decides to leave or move so that company can prevent the occurrence of turnover in other employees and can retain the presence of employees. The presence of employees can be maintained by making organizational commitment from employee to make employees give loyalty to the company. Commitment can encourage employees to conduct job amazingly, where they are not only thinking about their own success but also thinking about the success of company they are working at.

Organizational commitment shows that company that oriented to future tends to show bigger commitment towards their career and organization, so that the possibility of those employees to leave their present job is smaller (Park dan Jung 2015). Coversely, according to Saeed et al. (2014) shows that there is no significant relationship between organizational commitment towards turnover intention. According to him, based on current economical condition, every people want the best so that if someone has better opportunity and work condition needed, then organizational commitment will no longer useful in reducing their intention to move.

Next, according to Akar (2018), commitment is affected by employee perception towards quality of work life where they work, low work life quality can make employees experience fatigue and can prevent them to develop organizational commitment. This shows that, 
maintaining the presence of employees can be conducted not only by building an organizational commitment to the organization, the intention of turnover can be reduced by conducting evaluation towards employees through evaluation of quality of work life (QWL). Jabeen et al. (2018) shows that QWL has direct influence in reducing turnover intention in employees. Next Surienty et al. (2014) mentioned three components which influence turnover intention in employee, one of which is by paying attention to balance of life and work. Cascio (2006) defines QWL as employees perception concerning physical or mental prosperity condition of employees when working. Working employees not only see their payment side only but they also need convenience in working and its environmental situation, the opportunities of self-development, balance between life and work, appreciation and social relation in ther job. Farid et al. (2015) also explains that QWL has a very significant relationship towards organizational commitment, so that high QWL will increase organizational commitment to stay in a company.

The study case used in this research is companies which run in micro financing field, where this company has served several regions such as West Java, East Java, Central Java and Banten. During 2016 until 2018, this company experiences quite high turnover especially in account officer $(A O)$ level and based on Figure 1, the largest percentage of account officer conduct resignation in office of West Java Region amounted $43.5 \%$ per year.

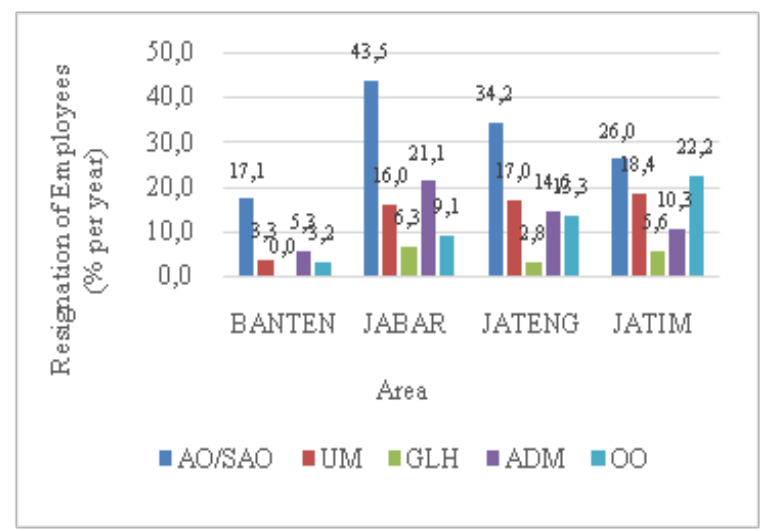

Figure 1. Percentage of Resignations in Each Position and Area in 2016-2018

(Sources: Company data, 2019)

Account officer is spearhead of financial or financing company, where the center of activity is in this position. Account officer in this company has tasks which socializing capital offering for business loans to housewife as debtor target, evaluate debtor candidate, withdraw the loan capital, conduct debtor business guidance and conduct deposit withdrawal everyday. Turnover problem that happen in this account officer requires company management to conduct evaluation to find put the proper strategy to be implemented in maintaining the presence of account officer especially competent account officer. This company has maximum turnover value of average 4\% per month but in position of account officer for this West Java region $\mathrm{n}$ the last three years, the turnover that happen is $6.8 \%$ in $2016,6.1 \%$ in 2017 and $6.4 \%$ in 2018 . The turnover value exceeds the maximum value predetermined by company. According to Indonesian Banks survey by Banking Professional Certification Institute 2018, it is mentioned that voluntary turnover rate is relatively high in level of 5-15\% percent, then turnover that happen in this company can be said as high.

Every account officer in this company has debtor who becomes their responsibility since the beginning before loans until repayment. If account officer changed so often, it can cause ineffectiveness and can influence the performance of other account officer, because other account officer must replace position of other account officer who resigned so that it adds workload. Based on problem description and theory that has been, to maintain the presence of account officer in this company and reduce the interntion of turnover that happen in account officer level, then employees who have high commitment are needed. This commitment can be made through fulfillment of QWL. The good fulfillment of QWL is expected can maintain and retent the employees this time also do not have intention to move. So that this research aims to analyze the influence of QWL towards organizational commitment and analyze the influence of QWL towards turnover intention through organizational commitment.

\section{METHOD}

The research location is region office in West Java. The sample of this research is all population of account officer employees in region office of West Java amounted 115 respondents. The data collection method is by conducting direct interview towards respondents using questionnaire. The type of data used is primary data and secondary data. Primary data was collected directly by respondents through questionnaire and secondary data was obtained from company, books and other literature. This research uses descriptive analysis and Structural Equation Modelling-Partial Least Square (SEM-PLS) analysis.

This research consists of three construct variables which are QWL, organizational commitment and turnover intention. The exogeneous variable in this research is work life quality, endogeneous variable in this research are organizational commitment and turnover intention. The explanation about these each variable is as follows:

\section{Quality of Work Life (QWL)}

According to Surienty et al. (2014) quality of work 
life (QWL) illustrates how far the relation of individual and their perception about life in its relation with environmental condition. Sajjad and Abbasi (2014) also defines QWL as employee reaction towards their job, especially towards their personal consequences on fulfilling their need and mental health. Farid et al. (2015) and Parvar et al. (2013) used eight aspects proposed by Walton about QWL. Indicator in QWL variable is adopted from eight aspects used by Walton (1973) which are (1) adequate and fair compensations, (2) safe and healthy working condition, (3) opportunity to use and develop human capacities, (4) opportunity to growth and security, (5) social integration in work organization, (6) constitutionalism in the work organisation, (7) work and total life space, and (8) social relevance of work life.

\section{Organiational Commitment}

Organizational commitment is considered as one of the important purposes of each organization to maintain the presence and the continuity of an organization (Hanaysha 2016). Organizational commitment is defined as desire of employees to remain member of an organization (Colquitt et al. 2013). Organizational commitment affects whether an employee still becomes member of organization (maintained) or leave to reach other job (turnover). Indicator in organizational commitment variable uses three types of commitment mentioned by Kreitner and Kinicki (2010) and Colquitt et al. (2013) which are (1) affective commitment, (2) continuance commitment, and (3) normative commitment.

\section{Turnover Intention}

According to Robbins and Judge (2013) turnover is level of employee resignation permanently, both voluntary or unvoluntary. Turnover intention is defined as conscious or intentional desire to leave organization (Tett dan Meyer 1993). Avanzi et al. (2014) explains turnover intention as runaway employee from unsatisfying work condition that can be worse because of bad work environment. This turnover can be seen as failure in relationship between employees and organization. Indicator in turnover intention variable adopts three cognition of turnover mentioned by Sager et al. (1998) and Saeed et al. (2014) which are (1) think to stop, (2) intension to seek, and (3) intention to stop.

Based on literature above, can be seen that Figure 2 shows SEM model from this research, and can be concluded that hypothesis of this research consists of:

H1: QWL has positive influence to organizational commitment.

$\mathrm{H} 2$ : Organizational commitment has negative influences to turnover intention.

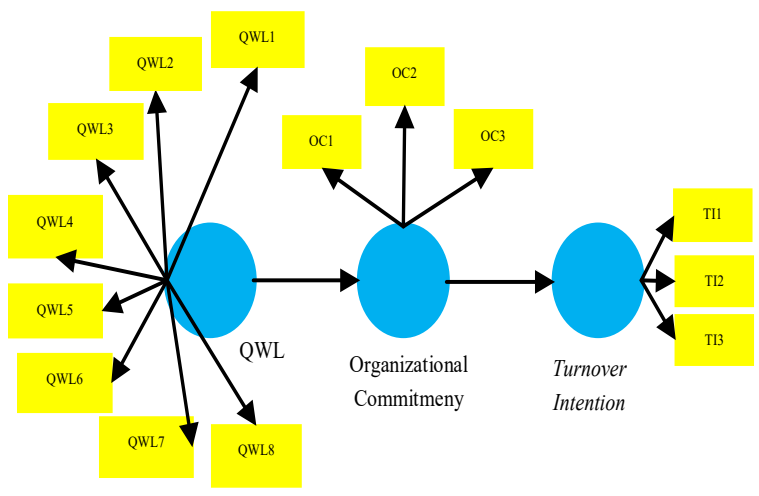

Figure 2. SEM Model

(Sources: Personal documentation, 2019)

Details $=$

QWL1 : adequate and fair compensations

QWL2 : safe and healthy working condition

QWL3 : opportunity to use and develop human capacities

QWL4 : opportunity to growth and security

QWL5 : social integration in work organization

QWL6 : constitutionalism in the work organisation

QWL7 : work and total life space

QWL8 : social relevance of work life

OC1 : affective commitment

OC2 : continuance commitment

OC3 : normative commitment

TI1 : think to stop

TI2 : intension to seek

TI3 : intention to stop

\section{RESULT AND DISCUSSION}

\section{Respondent Characteristic}

Respondent characteristic is illustration of respondent's identity in research location. Based on research result, there is respondent characteristic that be concluded. Respondent characteristic in this research includes gender, age, marital status, last education and work experience. Table 1 shows respondent characteristsic. Respondent consists of 115 respondents, with different employee status amounted 76 respondents with permanent employee status and 39 respondents with termporary employee status. All respondents are women, because this micro finance company for account officer position employs women labor, in addition, the target of debtor in this micro finance company is women or housewife, so that the approach is easier if account officer of this company are women.

The youngest respondent age in this research is 18 years old, while the oldest respondent is 30 years old. In this research, respondents are categorized to 18-20 years old, 21-25 years old and 26-30 years old. Most of the respondent age is in range 18-20 years old amounted 69 people or $60 \%$. The total respondents in age $21-25$ yeaars 
old amounted 40 people or $34.8 \%$ and the total of fewest respondent in age 26-30 years old amounted six people or $5.2 \%$. This because the company requires account officer to have minimal High School for the last education and the average is High School graduate in those range of age. According to company management, employees with younger age will have better physical ability compared to older employees. Account officer position has field job where strong physical ability is needed, therefore, company recruited employees with young age requirement.

Respondents in this company generally do not have family expense yet. Marital status is divided into two which are married and single. Most respondents are single amounted 89 people or 77.4. In addition, education is a capital for someone in working, because, by having education, someone can be said to have knowledge and skill. Last education of respondents only has two categories which are SMA/SMK and bachelor. Most of the respondents have last education in SMA/SMK level which amounted 113 people or $98.3 \%$, while last education in bachelor level is only two people or $1.7 \%$. This because this micro finance company requires account officer position with last education level mnimum SMA/ SMK.

Work experience in this research cosists of work period after graduate from school (SMA/SMK/Bachelor), work period in current company, work experience in other company and work period in other company. Work experience can be linked by having skill capital, high confidence and better understanding to jobdesk. Based on the result of research, how long working time after graduate from school (SHS/VHS/College) most are 1-2 year amounted 39 people or $33.9 \%$. Next, ho long employees work after graduate from school, there is category of less than six months which is 34 people or $29.6 \%$, the total is not different ftom respondent in category 1-2 years. This because most of the respondents have education level of SHS/VHS where they have not graduated from school so long so that how long they work after graduated is dominated by category 1-2 years and less than six months. Next, respondents who have more than three years work experience after graduate from school are six people or $5.2 \%$.

How long the work period in general related to level of loyalty and commitment owned by an employee. In category 1-2 years, has the largest number of respondents which are 46 people or $40 \%$. Next, the second category with the largest number which is less than six months amounted 39 people or $33.9 \%$. This shows that 39 respondents still in stage of observation or temporary employee where there are still many employees who have just get experience as account officer in this micro finance company.
Table 1. Respondent Characteristic

\begin{tabular}{|c|c|c|c|c|}
\hline \multirow{2}{*}{$\begin{array}{c}\text { No } \\
1\end{array}$} & \multicolumn{2}{|c|}{ Karakteristik } & \multirow{2}{*}{$\begin{array}{c}\mathrm{Jml} \\
69\end{array}$} & \multirow{2}{*}{$\begin{array}{c}\% \\
60.0\end{array}$} \\
\hline & Age & $18-20$ years old & & \\
\hline & & 21-25 years old & 40 & 34.8 \\
\hline & & 26-30 years old & 6 & 5.2 \\
\hline \multirow[t]{2}{*}{2} & \multirow[t]{2}{*}{ Marital Status } & Married & 26 & 22.6 \\
\hline & & Single & 89 & 77.4 \\
\hline \multirow[t]{2}{*}{3} & \multirow[t]{2}{*}{ Last Education } & SMA/SMK & 113 & 98.3 \\
\hline & & Bachelor & 2 & 1.7 \\
\hline \multirow[t]{5}{*}{4} & \multirow{5}{*}{$\begin{array}{l}\text { Work experience } \\
\text { time after gradu- } \\
\text { ated from school }\end{array}$} & $<6$ months & 34 & 29.6 \\
\hline & & $>6$ months & 23 & 20.0 \\
\hline & & $1-2$ months & 39 & 33.9 \\
\hline & & $2-3$ months & 13 & 11.3 \\
\hline & & $>3$ months & 6 & 5.2 \\
\hline \multirow[t]{4}{*}{5} & \multirow{4}{*}{$\begin{array}{l}\text { Work experience } \\
\text { time in current } \\
\text { company }\end{array}$} & $<6$ months & 39 & 33.9 \\
\hline & & $>6$ months & 17 & 14.8 \\
\hline & & $1-2$ months & 46 & 40.0 \\
\hline & & $2-3$ months & 13 & 11.3 \\
\hline \multirow[t]{3}{*}{6} & \multirow{3}{*}{$\begin{array}{l}\text { Have been } \\
\text { worked in other } \\
\text { companies }\end{array}$} & 0 times & 60 & 52.2 \\
\hline & & 1-2 times & 45 & 39.1 \\
\hline & & 3-5 times & 10 & 8.7 \\
\hline \multirow[t]{5}{*}{7} & \multirow{5}{*}{$\begin{array}{l}\text { Work experience } \\
\text { time in other } \\
\text { company }\end{array}$} & 0 years & 60 & 52.2 \\
\hline & & $<1$ years & 32 & 27.8 \\
\hline & & $1-2$ years & 18 & 15.7 \\
\hline & & $2-3$ years & 2 & 1.7 \\
\hline & & $>3$ years & 3 & 2.6 \\
\hline
\end{tabular}

(Sourced: Processed primary data, 2019)

Next, respondents who have work experience in this company in category 2-3 years are 13 people or $11.3 \%$.

60 respondents or $52.2 \%$ do not have experience of working in other companies. This can become the reason why there are many account officers who resigned from this micro finance company, because working becomes account officer is their first experience and it becomes milestone, next the desire of them to move to other places to get other new experiences and develop themselves. Respondents who have work experience 1-2 times in other companies are 45 people or $39.1 \%$ and respondents who have work experience 3-5 times in other companies are 10 people or $8.7 \%$.

Work experience in other company, can be seen how long they work in those other companies. Respondents who do not have work experience then have experience of working in other companies when $\mathrm{O}$ year amounted 60 people or $52.2 \%$. Respondents who have work experience time less than a year in other companies are 32 people or $27.8 \%$. Respondents who have work experience of 1-2 year in other companies are 18 people or $15.6 \%$. Respondents who have work experience time 2-3 year in other company are 2 people or $1.74 \%$ and more than three years experience are three people or $2.6 \%$. 


\section{Respondent's Perception}

Based on perception result of an account officer in this micro finance company, there are some that they consider as less fulfilled the criteria of work life quality. One of which is concerning working hour which is not compatible, burdensome workload, fatigue during working, time between life and work is not balance, and dislike to their superiors. If relate to intention of turnover, quality of life and working is not yet fulfilled, have higher intention of turnover. This problem becomes very important to be considered by company and it needs evaluation and improvement to make quality of work life more fulfilled.

\section{Result of Analysis on Strucktural Equation Modeling- Partial Least Square (SEM-PLS)}

In this research, testing is conducted to find out the influence of exogeneous latent variable (quality of work life/QWL) towards edogeneous latent variable (organizational commitment and turnover intention) and processed using SmartPLS 2.0. The testing model is divided into two, which are outer model (measurement model) and inner model (structural model). Outer model is conducted to analyze the relationship of indicator first order construct. While inner model to analyze the relationship of second order construct. This is the result of each test:

1. Analysis of Measurement Model (Outer Model)

Outer model is model which specify the relation of latent variable with its indicators. Evaluation of outer model is conducted towards first order reflected by its indicators. In analysis of measurement model, outer model test is conducted, where in this test, convergent validity, discriminant validity and composite reliability tests are conducted (Ghozali dan Latan 2015).

Convergent validity test can be concluded as valid by seeing the value of loading factor. Menurut Haryono (2017), loading factor value is said to be valid if $\geq$ 0.7. But for development of model or new indicator, loading factor value still can be accepted if the value between 0.5-0.6. If there is indicator which have smaller loading factor value than 0.6 then dropping process is conducted. Dropping is an elimination process of loading factor value in a research model so that proper loading factor value which is compatible with criteria can be obtained. In this research, dropping is conducted once, next, after dropping process is conducted, all loading factor has $>0.6$ so that the indicator used is valid and can measure each variable. The next evaluation is to test discriminant validity and composite reliability by seeing the value of Composite Relibiality (CR) and Average Variance Extracted (AVE). According to Haryono (2017), the limit value of $\mathrm{CR} \geq 0.7$ can be accepted and value of $\geq 0.8$ is very satisfying. AVE value illustrates the magnitude of manifest variable variety that can be owned by latent construct. The bigger the variety of manifest variable obtained by latent construct, the bigger the representation of manifest variable towards its latent construct. AVE value minimum 0.5 shows the good measure of convergent validity. AVE and $\mathrm{CR}$ values are presented in Table 2.

\section{Table 2. AVE Value and CR Value in Each Variable}

\begin{tabular}{|c|c|c|}
\hline Laten & AVE & $\mathrm{CR}$ \\
\hline \multicolumn{3}{|c|}{ Kualitas Kehidupan Kerja/QWL } \\
\hline QWL1 & 0.5063 & 0.8358 \\
\hline QWL2 & 0.5551 & 0.8321 \\
\hline QWL3 & 0.6193 & 0.8896 \\
\hline QWL4 & 0.5985 & 0.8163 \\
\hline QWL5 & 0.6799 & 0.8643 \\
\hline QWL6 & 0.6676 & 0.8576 \\
\hline QWL7 & 0.7294 & 0.8894 \\
\hline QWL8 & 0.6553 & 0.9044 \\
\hline QWL & 0.5033 & 0.9416 \\
\hline \multicolumn{3}{|c|}{ Komitmen organisasi } \\
\hline $\mathrm{OC} 1$ & 0.7627 & 0.9059 \\
\hline $\mathrm{OC} 2$ & 0.6973 & 0.9018 \\
\hline $\mathrm{OC} 3$ & 0.7865 & 0.9170 \\
\hline Organizational Commitment & 0.6369 & 0.9457 \\
\hline \multicolumn{3}{|c|}{ Turnover Intention } \\
\hline TI1 & 0.8954 & 0.9448 \\
\hline TI2 & 0.9075 & 0.9515 \\
\hline TI3 & 0.8692 & 0.9522 \\
\hline Turnover Intention & 0.7982 & 0.9651 \\
\hline
\end{tabular}

(Sourced: Processed primary data, 2019)

Based on result of test conducted, AVE value on each construct $>0.5$. This shows that construct can be said as valid and good. CR value in each construct $\geq 0.7$, then it can be concluded that indicators used which in the variable already have sufficient good reliability or already able to measure the construct.

2. Analysis of Structural and Hypothesis Model (Inner Model)

In this analysis, inner model test is conducted. Analysis of inner model aims to see the latent construct relationship in model so that it needs to conduct two tests. The first test is conducted by seeing the $R$-square value which is goodness-fit model test. The second test is conducted to see the significance of path coefficients. Values of $\mathrm{R}$ square in endogeneous latent variable are 0,$75 ; 0,50$ and 0,25, each represents substantial, mediym and weak accuracy level (Hair et al. 2011). Value of R-square can be seen in Table 3. 
Tabel 3. R-square Value

\begin{tabular}{cc}
\hline Variabel Laten & R-square \\
\hline Komitmen organisasi & 0.5548 \\
Turnover Intention & 0.3864 \\
\hline
\end{tabular}

(Sourced: Processed primary data, 2019)

Based on Table 3, R-square value of organizational commitment is $55.48 \%$ which shows that quality of work life (QWL) variable is able to explain the variety of organizational commitment amounted $55.48 \%$ and the rest $44.52 \%$ is explained by other variables outside the model. R-square value of turnover intention is $38.64 \%$ which shows that organizational commitment variable able to explain variety of turnover intention for 38.64\% and the rest $61.36 \%$ is explained by other variables outside the model. It can be concluded that organizational commitment has medium accuracy and turnover intention variable has weak accuracy.

The next stage of this research is testing to find out the path coefficient significance which shows the relation or influence between latent variable construct (second order). This test is called hypothesis test. Bootstrapping technique is conducted to answer hypothesis proporsed in this research. Bootstraping technique is re-calculation techinique of data sample randomly to obtain T-statistic value and original sampel by conducting path coefficients test. The result of path coefficients test using bootstrapping technique in this research can be seen in Table 4.

Based on Table 4, it can be concluded for hypothesis test in this research, which is as follows:

$\mathrm{H}_{1}$ : QWL has direct relation towards organizational commitment which is Positive. The result of T test in PLS output shows t-count value (2.7129) > T-table (1.96) means hypothesis accepted. This shows that the implementation of QWL in that company has significant and positive influence towards organizational commitment. The higher the QWL in company will improve the commitment of account officer to stay working in company. This research is in line wirh research conducted by Farid et al. (2015) which explain that QWL has significant relation towards organizational commitment in lecturer of Malaysian public research university. In addition, Parvar et al. (2013) shows that QWL affects the organizational commitment of employees to OICO company. According to him, by improving the quality of work life will improve the organizational commitment and employees can conduct more effective work.

$\mathrm{H}_{2}$ : Organizational commitment has direct relationship towards Turnover Intention which is Negative. The result of T Test in PLS output shows t-count value (4.5745) > T-table (1.96) means hypothesis is accepted. This shows that organizational commitment in account officer of micro finance company has significant and positive influence towards turnover intention. The higher commitment they have then the intention to move or to ge another job is decreased. This research is in line with research conducted by Nazarudin (2016), Rahmawati (2013) and Andini (2006) which mentioned that organizational commitment has significant and negative influence towards turnover intention.

Table 4. Result of path coefficients test using bootstrapping technique

\begin{tabular}{llll}
\hline \multicolumn{1}{c}{ Path } & $\begin{array}{c}\text { Original } \\
\text { Sample }\end{array}$ & $\begin{array}{c}\text { Standard } \\
\text { Error }\end{array}$ & T Statistics \\
\hline $\begin{array}{l}\text { QWL -> Organizatinal } \\
\text { Commitment }\end{array}$ & 0.3864 & 0.1424 & $2.7129^{*}$ \\
$\begin{array}{l}\text { Organizational } \\
\text { Commitment }\end{array}$ & -0.5902 & 0.1290 & $4.5745^{*}$ \\
$->$ Turnover Intension & & & \\
\hline
\end{tabular}

(Sourced: Processed primary data, 2019)

(Description: *have effect in real level 5\% with t-table value $=1.96$ )

In QWL variable, variable which most support the QWL based in result of PLS analysis is there is opportunities to develop capacity and talent for account officer in this company. The statement which most support that variable is conceningcompany in implementing wor performance in each account officer routinely. The performance assessment is a process conducted by each company to evaluate or asses the work achievement conducted by the employees. The purpose of this work assessment is as feedback in improving employee achievement and can be used to support in decision taking to conduct adjustment of compensation also promotion. Perfrormance assessment is also important to triger employee to improve their performances. Performance assessment in this micro finance company is routinely conducted once a month. Performance assessment through key performance indicator (KPI) by seeing the total of debtor guded by each account officer, the total of loan withdrawal and total of debtor in arrears. But, there are some things that must be considered by company to improve condition of good work life. This is about the work hour that is not suitable with the applied requirement, about payment given by company, where according to most of the payment respondents given cannot completely fulfilling, they life need. The next statement is about job and task of each emplotee that make them fatigue, there is no time tolerance when employees are sick so that when they cannot enter, then from that, respondents argue that there is tiresome when working in micro finance company. This also happen because their jobs have target every 
month. In addition, statement about the division of balance work time and rest time (work life balance) during work in this micorfinance company, most of the respondent asses it deficient, this also support their reasons to state that work hour which is applied is not in accordance with. And the last statement about social relation with work superior which considered as less satisfying, is about dislike with their superior and considered that the superios is less fair with their subordinates. Based on research result through questionnaire, the answer of respondent who complaints thatb those five things are considered as low, also stated want to stop or have intention to move to get better job. This shows that those five things really affect the intention of turnover account officer in that micro finance company.

Next, in organizational commitment variable, based on result of frequency distribution is in high category, but there are some affective commitment, contibuance commitment and normative commitment in medium category. Those statements concerning pleasure and happy feeling of finishing the rest of career on company, alternative opportunity of other company to move, feeling indebted to the company for what is given by the company and various benefits derived from the company so that they feel unworthy and feel guilty if leaving the company at this time. Those three statements do not influence their commitments. Employees who do not concern the fund needed or other lost and fear of there is no alternatife of other companies. Some respondents stated that they feel sire of leave their job this time because they will get better job compared to current job.

Next, in organizational commitment variable, based on result of PLS analysis, shows that organizational commitment always has significant and negative influence towards turnover intention. This shows that if organizational commitment is high towards company, it can reduce their turnover intention. Statement which mostly affects the organizational commitment is continuance commitment, where respondent stated there is difficulties for respondents to leave the current company, because there is not company which is comparable that can provide convenience. Payment, and other bettwe advantages. As said by respondents from research result through direct interview, they still have not got better job and they feel that this company can provide things they need such as convenience, better colleagues, and job which does not have shift schedule.

In turnover intention variable, statemet of having intention to move to other job in intention indicator to stop have the biggest influence towards turnover intention variable compared to others. This shows tat if there is better opportunity then they will choose to move to other workplaces. Most of the account officer is in productive age and in age group of Y Generation (birth period of 1982-2000) and graduated of High School, so that according to them, there are still many opportunities that can be obtained. In addition, there is big opportunities for respondent who have opportunities to themselves to get better job, so that respondent is mostly doubt in making statement of turnover intention.

In addition, if related to age category, high turnover is because their age is mostly in category of Y Generation group so that there are still feeling to looking for more. Y Generation in work world has different characteristic with previous generation. According to Gursoy et al (2013) Y Generation is a generation that less have respect towards their job and they have low relation in job or company. Y Generation easy to leave their job and looking for other new job which is compatible with their idealism (Oktariani et al. 2017).

\section{CONCLUSION}

Based on research result, in general, it can be concluded that quality of work life/QWL has significant and positive relationship towards organizational commitment. When work life is fulfilled and higher, it can improve the organizational commitment. Indicator which most influencing in quality of work life is opportunity to develop capacity and talent, which in statement about company implement performance assessment or work result achieved in each employee routinely. Next, organizational commitment has significant and negative influence towards turnover intention. It means, when organizational commitment towards company is high, it can reduce intention of turnover. The most influencing indicator to organizational commitment is continuance commitment, which is statement about respondent difficulties to leave this company is because there is no company which is comparable that can provide better convenience and other advantages. This shows that when QWL is fulfilled well, then it will influence the improvement of organizational commitment to stay in the company so that reduce the intention and desire of account officer to resign from the company. Several things that must be considered by company and need evaluation by company are considering work hour, workload, work life balance and evaluation of superiors towards their relation with their subordinates or account officer.

\section{REFERENCES}

Andini, R. 2006. Analisis Pengaruh Kepuasan Gaji, Kepuasan Kerja, Komitmen organisasi terhadap Turnover Intention (Studi Kasus Rumah Sakit Roemani Muhammadiyah Semarang) [tesis]. Semarang (ID): Universitas Diponegoro. 
Akar, H. (2018). The Relationships between Quality of Work Life, School Alienation, Burnout, Affective Commitment and Organizational Citizenship: A Study on Teachers. European Journal of Educational Research, 7, (2), 169-180.

Avanzi, L., Fraccaroli, F., Sarchielli, G., Ullrich, J. \& Dick, R. (2014). Staying or Leaving. International Journal of Productivity and Performance Management, 63, (3), 272-289. doi : 10.1108 / IJPPM-02-2013-0028.

Aydogdu, S. \& Asikgil, B. (2011). An Emperical Study of The Relationship Among Job Satisfaction, Organizational Commitment and Turnover Intention. International Review of Management and Marketing, 1, (3), 43-53.

Cascio, W.F. (2006). Managing Human Resources: Productivity, Quality of Work Life, Profits. $7^{\text {th }}$ ed. New York: McGraw-Hill/Irwin.

Colquitt, J.A., Lepine, J.A. \& Wesson, M.J. (2013). Organizational Behavior. New York: McGraw-Hill Irwin.

Farid, H., Izadi, Z., Ismail, I.A. \& Alipour, F. (2015). Relationship between Quality of Work Life and Organizational Commitmen among Lecturers in a Malaysian Public Research University. The Social Science Journal, 52, 54-61. doi: http://dx.doi. org/10.1016/j.soscij.2014.09.003

Ghozali, I \& Latan, H. (2015). Partial Least Squares: Konsep, Teknik dan Aplikasi Menggunakan SmartPLS 3.0, Edisi 2. Universitas Diponego.

Gursoy, D., Chi, C.G. \& Karadag, E. (2013). Generational Differences in Work Values and Attitudes among Frontline and Service Contact Employees. International Journal of Hospitality Management, 32, (1), 40-48.

Hair, J.F., Ringle, C.M. \& Sarstedt, M. (2011). PLS-SEM: indeed a silver bullet. Journal of Marketing Theory and Practice, 19, (2), 139-151. doi : http:// dx.doi. org/10.2753/MTP1069-6679190 202

Hanaysha, J. (2016). Examining the Effects of Employee Empowerment, Teamwork and Employee Training on Organizational Commitment. Social and Behavioral Sciences. 229, 298-306. doi: 10.1016/j.sbspro.2016.07. 139

Haryono, S. (2017). Metode SEM untuk Penelitian Manajemen : AMOS, LISREL \& PLS. Jakarta : Luxima.

Jabeen, F., Friesen, H., \& Ghoudi, K. (2018). Quality of Work Life of Emirati Women and Its Influence on
Job Satisfaction an Turnover Intention. Journal of Organizational Change Management, 31, (2), 352-370. doi: 10.1108/jocm-01-2017-0016

Kreitner, R. \& Kinicki, A. (2010). Organizational Behavior. New York: McGraw-Hill Irwin.

Lembaga Sertifikasi Profesi Perbankan. (2018). Menyiapkan Kompetensi Bankir di Era Disrupsi Teknologi Finansial. Seminar Nasional Vokasi Perbankan. Yogyakarta, Indonesia.

Nazarudin, D. (2016). Pengaruh Kepuasan Kerja dan Komitmen organisasi terhadap intensi Turnover pegawai PD Pasar Tohaga Bogor. Tesis. Program Pascasarjana Institut Pertanian Bogor.

Oktariani, D., Hubeis, A.V.S. \& Sukanda, D. (2017). Kepuasan Kerja Generasi X dan Generasi Y terhadap Komitmen Kerja di Bank Mandiri Palembang. Jurnal Aplikasi Bisnis dan Manajemen, 3, (1), 12-22.

Park, I. \& Jung, H. (2015). Relatinship Among Fututre Time Perspective, CareerandOrganizationalCommiment, Occupational Self-Efficacy and Turnover Intention. Social Behavior and Personality: An International Journal, 43, (9), 1547-1561. doi :http://dx.doi. org/10.2224/sbp. 2015.43.9.1547

Parvar, M.R.F., Allameh, S.M. \& Ansari, R. (2013). Effect of Quality of Work Life on Organizatinal Commitment by SEM (Case Study: OICO Company). International Journal of Academic Research in Business and Social Science, 3, (10), 135-144.

Rahmawati, MF. (2013). Analisis Turnover Intentions Karyawan KDS Cantonese Restoran Malang. Tesis. Program Pascasarjana Institut Pertanian Bogor.

Robbins \& Judge. (2008). Perilaku Organisasi. Edisi 12. Jakarta: Salemba Empat.

Saeed, I., Waseem, M., Sikander, S. \& Rizwan, M. (2014). The Relationship of Turnover Intention with Job Satisfaction, Job Performance, Leader Member Exchange, Emotional Intelligence and Organizational Commitment. International Journal of Learning \& Development, 4, (2), 242-256. doi: 10.5296/ ijld.v4i2.6100

Sajjad, N.K. \& Abbasi, B. (2014). Studying the Relationship between Quality of Work Life and Organizational Commitment. Research Journal of Recent Sciences, 3, (2), 92-99.

Sager, J.K., Griffeth, R.W. \& Hom, P.W. (1998). A Comparison of Structural Models Representing 
Turnover Cognitions. Journal of Vocational Behavior, 53, (2), 254-273.

Surienty, L., Ramayah, T., Lo, M.C. \& Tarmizi, A.N. (2014). Quality of Work Life and Turnover Intention: A Partial Least Square (PLS) Approach. Social Indicators Research, 119, (1), 405-420. Doi: 10.1007/s11205-013-0486-5

Tett, R.P \& Meyer, J.P. (1993). Job Satisfaction, Organizational Commitment, Turnover Intention and Turnover: Path Analyses Based on Meta-
Analytic Findings. Personnel Psychology, 46, (2), 259-293.

Walton, R.E. (1973). Quality of Working Life: What Is It? Sloan Management Review, 15, (1), 11-21.

Zhang, J.C., Ling, W.Q., Zhang, Z.Y. \& Xie, J. (2015). Organizational Commitment, Work Engagement, Person-Supervisor Fit, and Turnover Intention: A Total Effect Moderation Model. Social Behavior and Personality, 43, (10), 1657-1666. http:// dx.doi.org/10.2224/sbp.2015.43.10.1657e 